\title{
Are Kanak languages to be taught?
}

Social demands and linguistic dilemmas in contemporary New Caledonia

\section{Marie Salaun}

\section{(2) OpenEdition}

Journals

Electronic version

URL: http://journals.openedition.org/jso/1003

DOI: $10.4000 /$ jso. 1003

ISSN: $1760-7256$

\section{Publisher}

Société des océanistes

\section{Printed version}

Date of publication: 1 December 2007

Number of pages: 261-269

ISBN: 978-2-85430-010-9

ISSN: 0300-953x

Electronic reference

Marie Salaun, «Are Kanak languages to be taught? », Journal de la Société des Océanistes [Online], 125 | Année 2007-2, Online since 01 December 2010, connection on 02 May 2019. URL : http:// journals.openedition.org/jso/1003; DOI : 10.4000/jso.1003 


\section{Are Kanak languages to be taught? Social demands and linguistic dilemmas in contemporary New Caledonia}

by

Marie SALAUN*

\begin{abstract}
The 1996 census in New Caledonia reveals that there are more than 53000 speakers of the 28 Kanak languages spoken there. Of these 28 languages, only 6 are taught at school today, although the Noumea Accord (1998) officially states that Kanak languages are teaching and culture languages, together with French. This paper discusses the complex institutionalization of vernacular languages in formal education, after decades of repression in the name of assimilation, and the French republican egalitarism (and Jacobinism). On the basis of field data, it explores how even these days the recognition of Kanak languages has to overcome a multitude of obstacles. It addresses the subtle shift from the conditions under the former colonial domination to the new requirements of the postcolonial "common destiny".
\end{abstract}

KEYwORDS: Kanak, school reform, vernacular education, indigenous education, New Caledonia.

On the utility of the ecological metaphor: New Caledonia as a «hotspot»

Qualifying the contemporary linguistic situation in New Caledonia is a real challenge. Are we witnessing a «multilingual», «plurilingual», «diglossic context», or a «linguistic conflict»? A

\section{RÉSUMÉ}

Le recensement de 1996 en Nouvelle-Calédonie révèle l'existence de plus de 53000 locuteurs des vingt-huit langues kanak qui y sont parlées. Sur ces vingt-huit langues, six sont enseignées à l'école aujourd'hui, alors que l'accord de Nouméa (1998) stipule officiellement que les langues kanak sont des langues d'enseignement et de culture, à côté de la langue française. Cet article traite de la difficile institutionnalisation de la présence des langues vernaculaires dans l'éducation formelle, après des décennies de répression au nom de l'assimilation, de l'égalitarisme républicain (et du jacobinisme). À partir de données de terrain, il interroge la multitude d'obstacles que la reconnaissance des langues kanak doit surmonter aujourd'hui encore. Il aborde le subtil glissement qui s'est opéré, des exigences de l'ancienne domination coloniale à celles du futur « destin commun » postcolonial.

MoTS-CLÉs : Kanak, réforme scolaire, éducation vernaculaire, éducation autochtone.

plethora of rather vague characterizations, many qualitative uncertainties, as the only French is spoken, read or written by $97 \%$ of the total population, while approximately 75,000 Melanesians (Kanak) are active or passive speakers of one of the 28 remaining vernaculars,

* Université Paris v et GDR 2835 Nouvelle-Calédonie. Enjeux sociaux contemporains, marie.salaun@paris5.sorbonne.fr. 
according to linguists' estimations whereas the 1996 census mentions 53000 . Of those 28, eleven are spoken by more than 1000 people, and five are spoken by more than 5000 people.

An ecological metaphor appears to be notably accurate here: New Caledonia is famous for being what is nowadays called a «biodiversity hotspot», and, as are most of the «hotspots», is seriously threatened by the gravest aspect of the biodiversity crisis: the extinction of endemic species. New Caledonia is thus an ideal area for «conservation» projects.

Applied to the linguistic field, the general opinion is that unification is under way, considering how fast linguistic skills seem to vanish, from one generation to the next one: in 2000, while $33 \%$ of their parents declared a vernacular to be their «primary language», $70 \%$ of sixth grade children affirmed not knowing any vernacular (Veyret and Gobber, 2000).

Even if the «biological» metaphor is useful, it keeps the debate within the constricting confines of a framework which revolves around terms such as «endangerment», «extinction», «conservation», «revitalization», etc. without providing guidance as to how conservation politics should be focused on the ground. This requires a more contextualized perspective: if identifying conservation priorities is crucial, what is at stake in New Caledonia today?

To address the various dilemmas that conservation policies face, this paper will focus on a particular aspect of the politics of revitalization of Kanak tongues: their implementation as instruction subjects in formal education.

This needs to be contextualized by mentioning the various «threats» to those languages, which brings us back to a paradoxical colonial process which both marginalized and contributed to the protection of Kanak languages. I will first argue that the denial of indigenous cultural realities was compensated by the absence of an effective assimilation policy. Identifying these dangers also brings us back to a more recent postcolonial context. The second section will demonstrate how francophonie, seen here as a belief in the superiority of French language, has constituted a serious obstacle to the revitalization policies, and moreover, how the «francophile» reactions towards Kanak cultural claims in the last 30 years have contributed to highly «politicized» (and therefore obscure) linguistic issues. I will lastly examine local perceptions about indigenous languages, bringing to light the set of questions that have arisen after the implementation of vernacular teaching at the pre-elementary and elementary school levels.

\section{The colonial experience in New Caledonia: an uncompleted frenchification}

The conditions under which French has been imposed create a contemporary situation that is more diglossic than bilingual, and some recent linguistic surveys (Barnèche, 2004; Fillol and Vernaudon, 2004) underline the effects of these unilingual and glottocentric politics in a plurilingual context: linguistic insecurity, rejection of the dominant culture, symbolic overestimation of an indigenous language which is no longer fully mastered, construction of a local French vernacular in reaction to standard French, etc. The unequal status of languages has favoured a situation in which each language is invested with distinct communicative functions and social roles; it is therefore common to hear Noumeans refer to vernacular languages as «the languages of the heart» while French is considered «the language of reason».

It is important to make a detour through the process which has led to the minimization of indigenous languages, for this really is an issue of minimization and not eradication.

What happened in New Caledonia during the colonial era (1853-1946 strictly speaking) is quite unique in the history of the French Empire. Using a psychoanalytical metaphor, I will argue that the suppression of the native population paradoxically offered a valuable protection to their languages.

Officially, France took possession of New Caledonia in 1853. The military had been preceded by missionaries from the London Missionary Society and the Marist Catholics, together with Franco-British rivalry for the domination of the South Sea Islands. Initially founded as a penal colony, New Caledonia became a pioneering frontier for «free» settlement at the beginning of the twentieth century (Merle, 1995). The mainland French never emigrated en masse to this distant land, which had the bad reputation of being settled by former convicts and so-called «cannibals». Unlike other parts of the French colonial Empire, the Melanesians were systematically pushed out of the way into reserves as early as the 1890s (Saussol, 1978). Locking up the natives made it necessary to recruit indentured workers from Java, Indochina and the New Hebrides, to cultivate the fields and work in the mines. The multiplicity of native languages (roughly 30 ), and the many languages of the imported populations, «naturally» made it mandatory to use the coloniser's language as the common vehicle. From 1863 and up until the end of the colonial period, in 1946, French was imposed by 
law, and was the only language authorized in schools and publishing. It is an example of the ideological substratum that Louis-Jean Calvet (1974) has called glottophagie in French (linguistic cannibalism), which involves replacing all the vernacular languages with French. Yet, remarkably - given the violence of the colonial process in New Caledonia - French did not eliminate the indigenous languages, rather, it was added on top; the extraordinary vitality of the Kanak languages bears witness to this, since only one out of approximately 30 has been swept away by colonisation.

The colonial government of New Caledonia never went to the trouble of «frenchifying» the Kanaks. Assimilation, which implies mastering the language of the Mother-country, was never a serious proposition for people who, to use colonial phraseology, were supposed «to bow down in front of the superior peoples». Alban Bensa qualifies this colonial relationship as a «racism of annihilation» and as an «ideology of Melanesian extinction» (Bensa, 1995: 114). But suppressing the native element had a direct consequence: the absence of an indigenous policy, or the mere implementation of a stand-by policy, until after World War One.

In fact, the Administration left it largely to the representatives of the two religions present in the field to civilize the natives. But Catholics and Protestants were more concerned with christianising than «civilizing», in the sense that France, which had separated the Church from the State in the early twentieth century, understood the term to mean. It would be closer to the truth to say that Christian preachers viewed the native languages as a means of spreading the Word of the Lord, rather than as an obstacle. De facto, as the alumni of the native schools whom I met testified, Kanak languages have always been tolerated in schools, and mastering the coloniser's language was always felt to be a last resort, albeit vital to soften the daily hardships and injustices inherent in the legal regime governing the native population (Salaün, 2005).

Finally, the last important landmark of colonial times, francophonie (as the use of the French language) was not upheld by any of New Caledonia's native elites, unlike in other African or Asian possessions, where a caste of Frenchspeaking nationalist leaders grew up between the two World Wars and took over the new States when decolonization began. This did not occur until the 1970s in New Caledonia.

\section{From colonial banning to postcolonial native claims: a highly politicized issue}

The first decree banning indigenous languages in the public sphere (schools and publications) dates back to 1863 . The position of the New Caledonian authorities had the advantage of being relatively easy to grasp throughout the colonial period: French was the sole authorized language (Rivierre, 1985). But, as previously stated, one must not over-estimate French linguistic imperialism in New Caledonia during that period of time, given the form it has taken. Of course, there as elsewhere, official rhetoric declared it was necessary for the colonised peoples to learn the language which would enable them to enter the «modern» and «civilized» world. Of course, there as elsewhere, one could tell that the native languages were looked down upon and never acknowledged as real "languages». But there was no obsession with «gallicizing». The shift towards the affirmation of the necessity of an «all-French» system would come later, when «assimilation» became the official goal, after World War II.

A continuity between the colonial and the post-colonial periods is nonetheless observable: «linguistic» issues have always been highly politicized. Yet, while essentially being «White man's business» during the colonial era, these issues have clearly crystallised the controversy between pro and anti-independence camps ever since the 1970s.

During the colonial era, the defence of French was above all used by Whites among themselves in order to stigmatize their political opponents. It thus might be said that the utilisation of the language issue turned it into «White man's business».

Within the New Caledonian white society the first cleavage opposes the representatives of the secular State to those of the Missions, particularly the Protestants. The language of instruction has always been a means of denouncing the anti-establishment forces the two missions would represent. Civil servants and colonisers generally joined forces against them to deplore their "pernicious» influence on Kanak people. Catholic missionaries were not at the heart of such polemics: their personal origins (Mainland France) and the official stand taken by their hierarchy would free them from the suspicion of «antiFrench» manœuvres. The anticlerical party focused much more on the exploitation of children in the Mission fields than on the use of mother tongues in schools. Protestants were much more directly attacked. To take but one 
example, the pretext for annexing the Loyalty Islands in 1864 was the fact that the schools of the London Missionary Society founded by Reverend Mc Farlane didn't respect the terms of the 1863 decree, which stated that French was the only language permitted in education. Some twenty years later, the replacement of the British London Missionary Society by the French Mission de Paris is a non-event in the sense that detractors seem to have kept in mind a close link between Protestantism and British influence. Both evangelizing strategies and teaching methods were considered seditious. The role played by Polynesian natas in the nineteenth century, and later on by Loyaltians and Kanaks from the Main Island (Grande-Terre in French) in the propagation of the Gospel message would obviously not disseminate the ideal French influence missionaries were expected to spread throughout the colony. The use of the vernaculars was closely associated with the support of an indigenous «rebellion» against French authorities. The arrival of Maurice Leenhardt (see Clifford 1992) at the very beginning of the twentieth century somehow calmed the situation down, though his personal interest in learning and transcribing Ajië (Houaïlou language) gave rise to mistrustful reactions among the white settlers.

The second cleavage opposed the French Administration to the French colonisers. The settlers were accused of wanting to keep the Kanak from learning French, «the language of the Human Rights», in order to better exploit them. The civil servants were accused of serious carelessness regarding the control of native schools.

In that respect, the following excerpt from a discussion which took place at the General Council in 1914 is representative of these accusations:

"Who is in charge of controlling native schools? Anyone who travelled [out of Noumea] has been surprised to notice that almost everywhere, these schools are abandoned: in several of them, not only do pupils not understand French, but I even saw teachers who could hardly speak our language.» (Conseil général, 16 Dec. 1914)

The linguistic polemic was very instrumental: it allowed the settlers that were elected representatives to refuse to fund native education. The following debate took place in 1916, just after a majority of the settlers' representatives rejected the Administration's budget proposal and spoke out for the suppression of all credits:

«[The Administration representative:] Native schools have not always been satisfying, this could be said, but we have witnessed serious improvements in the last two years, and, giving ourselves some time, we could achieve some very satisfying results [...].

[The president of the elected assembly:] I suggest that the Administration do something so that native schools will no longer be a real joke, and, notably, pay attention to the fact that instruction must be given in French $[\ldots]$.

[The Administration representative:] What we have already achieved is not that bad, and many natives can read, write and count $[\ldots]$.

[The president of the elected assembly:] Unfortunately, they learn in Lifou or Mare, but not in French. I'll never protest enough against a system which results in $9 / 10$ of the letters that are sent [from the battlefield in Europe] by Kanak native infantry being written in Kanak dialect instead of French [...].» (Conseil général, 14 Nov. 1916)

If the linguistic polemics is somehow internal to the white society (the Kanak themselves being totally deprived from any say in the matter) during the colonial era, the 1970s put a radical new face on the relationship between French and vernacular languages. At that time, after three decades of French citizenry which did not bear witness to any significant improvement in their condition, the Melanesians started to make nationalist demands. Their number had dwindled due to a century-old immigration policy, so they only represented $43 \%$ of the population in this territoire d'Outre-Mer, and a minority in the electoral roll. The question of how the twentyeight remaining vernacular languages should be considered clearly became something that crystallized the conflict between «Independentists» and «Loyalists» (pro-French).

Preceding the nationalists' political claims were land claims (the Independentists demanded the restitution of the land of their ancestors that the colonisers had confiscated), and cultural claims (demands that the culture of the first inhabitants be legally recognized). Re-enhancing the vernacular languages, especially by including them in the school curricula, was at the heart of these «cultural» demands. The first official request to recognize Melanesian specificities in schools goes back to 1971, when the locally elected representatives asked that the Deixonne Law, which governs the teaching of Regional Languages in Metropolitan France since 1951, should be applied in the Territory. The Administration's response deserves to be quoted at length, so revealing it is concerning the foundations of the ideology of francophonie, henceforward definitely assimilationist, and because of its explicit depreciation of Kanak culture. Here is what the Vice-Rector appointed in Noumea responded in 1975 when consulted on the validity of the request: 
«[In elementary school] we seem to agree that two main reasons explain the relatively feeble mobility of Melanesians at the school and university level; on the one hand, the insufficient mastery of the French language by a great number of natives, and, on the other hand, and correlatively, a certain awkwardness when applying European concepts [...]. The role of elementary school is to give the children the means for communicating, orally and in writing, which are indispensable if one wants to integrate in a changing society. In light of the foregoing, one can only stress the need for a place where the French language can be used uninterruptedly.

[In secondary school] it does not seem justified to compare [the Kanak tongues] with some of the large regional languages of Metropolitan France, which support a literature and in many cases have served as a means of communication for hundreds of thousands of people. The presence of Melanesian vernaculars in the final exams for the baccalauréat is thus not a valid proposition, either now or in the near future.» (ViceRectorat de la Nouvelle-Calédonie, 1975: 3)

When faced with such a put-down, the question of which place the French language should occupy quickly took on a truly political dimension - and in both the Independentists' and loyalist camps.

In the Independentist camp, in 1984, one of the first decisions made by the newly elected majority led by Jean-Marie Tjibaou was to abolish the entire set of legal dispositions inherited from the colonial period that prohibited the use of Kanak languages in schools and publishing (Sam, 1996). One year later, when school started again in March 1985, the independentists took advantage of the «events» that had started in November 1984 and launched a boycott of the «colonial» schools. This gave birth to short-lived community schools, called Écoles populaires kanak, where teaching was done in the vernacular, and the contents thought out in ways considered to be more compatible with Kanak cultural realities (Gauthier, 1995).

As to the «Loyalist» camp, Jean-Claude Rivierre wrote in 1985:

«the attachment to the mainland and its language was the New Caledonian White society's credo for a long time.» (Rivierre, 1985:1683)

As the conflict became increasingly violent, all opposition to the monopoly of French in the public sphere was taken as a protest against the presence of France and French nationals, and even seen as a threat to the integrity of the French Republic.

During that period of near-civil war, prudishly known in French as «the events», francophonie was definitely of a «sovereign» sort, and its opposition by the Kanak Independentists was less a refusal of the French language per se than a rejection of the symbolic significance of defending an «all-French» system.

\section{Toward a «multilingual» school system?}

In a postcolonial context, vernacular languages as subject matters in formal education seem to face both «political» and «pedagogical» difficulties. As in other linguistic contexts with oral tradition and limited numbers of speakers, pedagogical difficulties are not lacking in New Caledonia. From the works of missionaries to those of «professional» researchers, the written descriptions of Kanak vernaculars are rare and in any case concern only a small number of them. As a consequence, there is an absence of readily usable pedagogical materials in classrooms and an absence of adequate teacher training. The linguistic heterogeneity of students, especially in Noumea, does not facilitate the implementation of vernacular instruction.

Nevertheless, these technical difficulties do not explain either the slowness or the parsimony with which the Kanak languages have been recognized in the school system so far. From the ideology of francophonie to the obsession with defusing the nationalist bomb, political obstacles have always been more decisive than pedagogical issues.

These political obstacles no longer existed after 1988, at least officially, as the signature of the Matignon-Oudinot Accord in 1988 between the French State, the Loyalists and the Independentists brought about the return to civil law and order in the Territory. In 1998, the Noumea Accord engaged New Caledonia in a process of decolonization relatively unheard of in the history of the French empire, as its preamble stipulates:

«Decolonisation is the way to rebuild a lasting social bond between the communities living in New Caledonia today, by enabling the Kanak people to establish new relations with France, reflecting the realities of our time. [...]. It is now necessary to start making provisions for a New Caledonian citizenship, enabling the original peoples to form a single human community, asserting their common destiny with the other men and women living there [...]. Ten years on, a new process will need to commence, entailing the full recognition of Kanak identity, as a pre-requisite for rebuilding a social contract between all the communities living in New Caledonia, and entailing shared sovereignty with France, in preparation for full sovereignty [...]. The past was the time of colonisation. The present is a time of sharing, by achieving a new balance. The future must be the time of identity, by partaking in a common destiny [...]. France stands ready to accom- 
pany New Caledonia on that path.» (Journal officiel de la République française, 1999: 4197-4233. Informal translation done by the Pacific Community translation services for the Embassy of France in Australia)

The 1998 Accord also defines a framework through which the new relations were to be put in place between French and the other languages, at least the Kanak languages. It stipulates that:

«[t]he Kanak languages, together with French, are the languages of education and culture in New Caledonia. Their place in school curricula and in the media should therefore be increased and extensive thought should be given as to how to achieve this goal.»

From 1988, the successive Accords, relying on a relative political consensus, have allowed for new directions in educational policies. A new sharing of responsibilities has emerged from the renewed legislative frame and institutions.

Under the Matignon Accord, France retained responsibility for all general matters: curricula, pedagogical methods, and teacher supervision. New Caledonia was divided into three Provinces (Southern, Northern, Loyalty Islands), each with enlarged powers. Each Province is free to decide «the kind of adaptation required by the local cultural and linguistic realities» in primary education. In 1990, a letter from the French Minister of National Education provided the basis for local adjustments:

«In primary education, vernacular languages must take their place where and when provincial authorities have decided it. It is essential that the practice of such languages not be marginalised, separated from other learning. A strong coherence must be sought, for the benefit of the children, between their cultural identity and the subjects that are taught.» (Jospin, 1990)

This learning could not exceed five hours a week. In practice, two of the three Provinces launched experimental (and rather small-scale) plans: EILM (Enseignement intégré dans la langue maternelle - Mother Tongue Integrated Learning) for the Loyalty Islands Province, PHAX (Paicî, Hoot ma Whaap, Ajië, Xârâcùù - the names of four vernaculars) for the Northern Province. As no evaluation of the impact of these provincial plans has been made, it is impossible to give any assessment, though one can assume that the proportion of children who actually attended mother tongue classes is low.

More substantial progress was made in secondary education, with the recognition of four Kanak languages to be taken as one of the baccalauréat $^{1}$ subjects. At the 1996 baccalauréat session, more than 130 candidates (roughly a third of all Kanak candidates) took their mother tongue as a compulsory or optional subject.

Under the Noumea Accord (1998), which serves as a roadmap for the gradual transfer of powers from metropolitan France to local authorities over a twenty-year period, primary education has been placed under the responsibility of New Caledonia's local government since 2000. Curricula definition, teacher training, recruitment and supervision are no longer controlled by Paris. In a certain sense, the implementation of Kanak languages has become a strictly local issue, and the difficulties it faces are no longer to be sought in any «Republican» French glottocentric attitude or Jacobinism. Keeping this in mind, I will argue that beyond the new political (and «multicultural») consensus, one must not overestimate the depth of change in attitudes on the part of New Caledonians. It has become politically incorrect to question the orientations of the Noumea Accord, and even if one is reticent about the end of the monopoly of French, one no longer says so in public but, in practice, vernacular languages still prove that there are certain difficulties involved in institutionalizing and generalizing them as languages of instruction. I will illustrate this statement using the conclusions drawn from a research project I conducted in 2004 on families involved in an experiment in teaching Kanak languages in kindergarten and the first year of elementary school. As an anthropologist of education, I was asked by the New Caledonian government to participate in the evaluation of this experiment and to determine if what was proposed would satisfy the demands of the families, communities, and the decentralized administrations. A psycholinguist, Isabelle Nocus, was in charge of quantitatively evaluating the measurable effects of this project on the children (principally along three axes: self esteem, competency in the vernacular, improvement in French) $)^{2}$.

1. Baccalauréat is a national exam taken at the end of secondary schooling which determines eligibility for higher education.

2. This applied anthropological research was part of a larger project of mine on linguistic representations. I have worked on two very different levels in the course of my work in New Caledonia: a «macro» level which deals with global linguistic policies from a historical perspective, and a «micro» level which deals with family interactions and linguistic socialization. The question of representations appears to be crucial to provide the missing link between those two levels, and notably account for some contemporary paradoxes. At a «macro» level, the loyalist encouragement of the instruction of Kanak languages seems to 
The experimentation was based on three original principles:

- It concerned State kindergarten and elementary schools. (The enrolment rate is close to $100 \%$ in pre-elementary schooling, which begins at the age of three.) Previously, in the State school system only secondary and higher education were concerned with the teaching of Kanak languages.

- It was dedicated to testing a training program for Kanak teachers recruited with a bachelor's degree from the University of Noumea and its new department «Regional languages and cultures» (and, eventually, it would provide employment opportunities for the prospective students of this department...)

- Every child, from the age of three, attended a mother tongue class for an hour every day, given by a «monolingual» teacher specialized in this teaching, in a separate classroom.

At its inception at the beginning of school year in 2002, there were three trainee teachers (two Drehu speakers and one Ajië speaker). Two years later, eight trainee teachers taught five different languages. More than 200 children were concerned.

The program ended with the close of the school year in 2004, and was not extended for 2005. That decision was taken even before the results of the evaluation of its impact were published in December 2004 (Salaün, 2004; Nocus et al., 2004). Succinctly put, what the evaluation would show was that all goals had been achieved, with the exception of the expected positive influences on the acquisition of French language. This is not, in itself, a surprise considering the age of the children involved (from three to six) and the length of the experiment (no more than two years). At the beginning of 2005 , a potential generalization came up against an obstacle: the lack of agreement on the definition of objectives assigned to this teaching. Three main goals, potentially contradictory, could be identified:

- facilitate the acquisition of French («additive bilinguism» theory);

- comfort the Kanak cultural patrimony;

- prevent school failure by avoiding the cultural discontinuities a young Kanak child is confronted with during the first years of schooling.

No consensus about the hierarchy of these goals was found at that time.
New curricula were finally adopted by the local assembly in September 2005, stating:

«The teaching of Kanak culture and languages is under a progressive generalization [in primary education], on the Provinces' initiative regarding their linguistic and cultural realities, linguistic knowledge, pedagogical tools and available resources [...]. The teaching of Kanak culture and languages is the matter of an organization to be specified in the school project. It is taught to pupils whose parents have expressed their consent, by qualified teachers, seven hours a week in kindergarten and five hours a week at the elementary level. To manifest their being languages of instruction, Kanak languages are to be taught through the various subjects.» (Congress of New Caledonia, Déliberation $n^{\circ} 118,26$ Sept. 2005: art. 6)

It has to be mentioned that these new curricula were not adopted with the support of independentists parties' representatives (forming the FLNKS - Front de libération nationale kanak et socialiste), who voted against them, judging them too «conditional» on the teaching of indigenous languages. The following day, on $28 \mathrm{Sep}-$ tember 2005 , the (single) local daily newspaper ran the headline:

«Primary school curriculum: Congress mumbles about Kanak languages.» (Les Nouvelles calédoniennes, 2005)

In fact, the debates that surrounded this recent reform of the educational system reveal the extent to which the «denial of the didactic function of Kanak languages» (see Fillol \& Vernaudon, 2004) subsists to this day. Significantly, the text was voted with the support of the Rassemblement-UMP party (ex RPCR - major loyalist party), who obtained a generalization to second to fifth form only after an adequate evaluation of its pedagogical value will have been made. The Rassemblement-UMP brief on the objectives of the amendment published on 21 September 2005 states:

«[an evaluation] was done exclusively in kindergarten. Its conclusions were, of course, that the disposal had been efficient for the Kanak language (Drehu) and that it had not interfered with the learning of French. As far as elementary school is concerned, no experiment has been conducted so far, a fortiori no evaluation in order to determine whether continuing to teach the Kanak languages is in the best interests of children. Yet the important question to raise is precisely to determine if this teaching will cause delays for the involved children, particularly in fundamental subjects such as French and Maths: what part of these subjects will not be given in French: conjugation of verbs? Plural of adjectives? Fractions? Percentages?

condemn it to death... At a «micro» level, parents are very ambivalent, proclaiming their attachment for the mother tongue and increasingly using French in their daily interactions with their children... 
[... As a consequence, you are being proposed an amendment, stipulating that the continuation of Kanak languages teaching from grade two to grade five will be in effect only after a scientific experiment has shown its real interest for the children»s success.» (Amendment $\mathrm{n}^{\circ} 1$, presented by Rassemblement-UMP, 21 September 2005)

Thus, the supporters of bilingual education are constantly called upon to guarantee that the «interests of the child» will not be crucified on the altar of political concessions. The consensus that finally emerged in New Caledonia rests in reality on accepting some sort of «transitional bilingualism», meaning that the only objective that can validly justify the presence of minority languages in school is facilitating the acquisition of French, which seems to remain the exclusive legitimate teaching medium. "Francophonie» thus still seems to have a brilliant future in New Caledonia: $90 \%$ of the people living there declare they speak, read or write French. In the past 20 years we have even seen the development of a Kanak literature in French, such as the work of Dewé Gorodey, a poet and the Independentist Vice President in the local government. At the apex of nationalist protest, Jean-Claude Rivierre wrote:

«Beyond its properly symbolic aspect, the French language was never seriously threatened in New Caledonia?» (Rivierre, 1985:1716)

This remark is all the more true today since there is no alternative to French as the language of the future multicultural citizenship.

\section{Conclusion}

In conclusion, we must remember that, no more here than anywhere else, does the question of revitalization exist independently from the social realities, class struggles, interethnic relations, and, in fine, the linguistic situation. Therefore, I willingly follow Sophie Barnèche (2004: 54 ) when she proposes to qualify the New Caledonian situation as being a linguistic conflict in which

«two clearly distinct languages are opposed, one politically dominant (imposed in all official and public business) and the other politically dominated. The characteristic of the linguistic conflict between the dominant language (French) and the dominated languages (Kanak and other minority languages), is that it is always largely masked by an ideology that "establishes the complementary relationship between languages or linguistic varieties", and thereby renders "the inevitable outcome of the uneven power struggle invisible".»
New Caledonian citizenship, aimed at becoming a «common destiny», tends to hide the fact that the communities in New Caledonia are not only different «culturally», but also very unequally blessed with economic, social, and cultural capital, in the sense coined by Pierre Bourdieu. In fact, defining the potential «new relationship» between the vernacular languages and French is rather perilous, as the following excerpt from an interview with Marie-Noëlle Thémereau, presently the President of the New Caledonian Government, demonstrates:

«Working on our commonly held values [in school] is indispensable to prepare the child to recognize the "other" in their difference, that is in their identity; that recognition depends, for example, on reconciling the Kanak languages and French, which will no longer be opposed in school but will cooperate in aiming at our children's success, by taking into account the fundamental role of the mother tongue in the young child's harmonious development and personality building. Kanak language, the language of the heart, the language of the ancestors, the language of the elders and of the roots, must also become, for the children whose mother tongue it is, the language of learning [...]. In exchange, French, the vehicular language, the language of sharing, of getting to know the others, the language of Caledonian citizenship and of achievement in school, will gain renewed legitimacy.» (Sentiers, 2004: 9)

The permanence of the commonplace that opposes the language «of reason» (French) to the language «of the heart» (the mother tongue) shows how difficult it is to find a new legitimacy in a post-colonial context. Of course, the linguistic issue has been modernised and updated... but beyond its cosmetic «new look», we can reasonably say that the project of assimilation it had backed in the past remains latently present.

\section{BIBLIOGRAPHY}

BARNÈCHE Sophie, 2004. L'identité linguistique et culturelle des jeunes de Nouméa. Une étude des pratiques langagières dans la cité de Riverstar (Rivière Salée), thèse de doctorat nouveau régime en sociolinguistique, dirigée par Claude Caitucoli et Véronique Fillol, université de Rouen.

BENSA Alban, 1995. Chroniques kanak. L'ethnologie en marche, Paris, Ethnies documents 18-19.

Calvet Louis-Jean, 1974. Linguistique et colonialisme. Petit traité de glottophagie, Paris, Payot.

Clifford James, 1992. Person and Myth: Maurice Leenhardt and the Melanesian World, Durham, Duke University Press.

Fillol Véronique et Jacques VernaUdon, 2004. Les langues kanak et le français, langues d'enseigne- 
ment et de culture en Nouvelle-Calédonie : d'un compromis à un bilinguisme équilibré ?, ELA 133 , pp. 55-67.

GAUTHIER Jacques, 1996. Les écoles populaires kanak. Une révolution pédagogique?, Paris, L'Harmattan.

Gobber Marie-Joëlle et Marie-Paule Veyret, 2000. Quelles langues utilisent nos élèves? Analyse d'une enquête faite auprès des élèves de sixième des collèges publics de Nouvelle-Calédonie, Nouméa, publication du CNDP/IUFM du Pacifique et du Vice-Rectorat de Nouvelle-Calédonie.

Jospin Lionel, 1990 (28/02). Lettre du Ministre de l'Éducation Nationale, de la Jeunesse et des Sports au Vice-Recteur de Nouvelle-Calédonie, CAB/5 $\mathrm{N}^{\circ} 1759$.

Journal officiel de la République française, 1999 (19/03). Loi 99-209, pp. 4197-4233. Translation: http://www.ambafrance-au-

org.article.php3?id_article $=1058 \& v a r \_r e c h e r c h e=$ accord+de+nouméa

Les Nouvelles calédoniennes, 2005 (27/09). «Programme du primaire : le Congrès bafouille sur les langues kanak », p. 1 .

Merle Isabelle, 1995. Expériences coloniales. Nouvelle-Calédonie, (1853-1920), Paris, Belin.

Nocus Isabelle, Agnès Flandrin et Philippe GuIMARD, 2004. Évaluation de l'expérimentation
"L'enseignement des langues et de la culture kanak à l'école primaire de la Nouvelle-Calédonie», rapport de recherche remis au gouvernement de la Nouvelle-Calédonie.

RIVIERRE Jean-Claude, 1985. La colonisation et les langues en Nouvelle-Calédonie, Les Temps modernes, 464, pp. 1688-1717.

SALAüN Marie, 2004. Les langues kanak à la maternelle. Contribution à l'évaluation de l'expérimentation DENCIIFMNC. Aspects sociolinguistiques, rapport de recherche remis au gouvernement de la Nouvelle-Calédonie.

—, 2005. L'école indigène. Nouvelle-Calédonie. 18851945, Rennes, Presses universitaires de Rennes, collection Histoire.

SAM Léonard, 1996. Vernacular Languages and Education in New Caledonia, in F. Mugler and J. Lynch (eds), Pacific Languages in Education, Suva, Institute for Pacific Studies, pp. 76-91.

SAussol Alain, 1979. L'héritage. Essai sur le problème foncier mélanésien en Nouvelle-Calédonie, Paris, Publications de la Société des Océanistes 40.

Sentiers, 2004 (7/07). Le magazine de l'école en Nouvelle-Calédonie, 7, p. 9.

Vice-Rectorat de la Nouvelle-CalÉdonie, 1975 (23/07). Note sur l'enseignement des langues et de la culture mélanésienne, 19-5753, 8 p. 